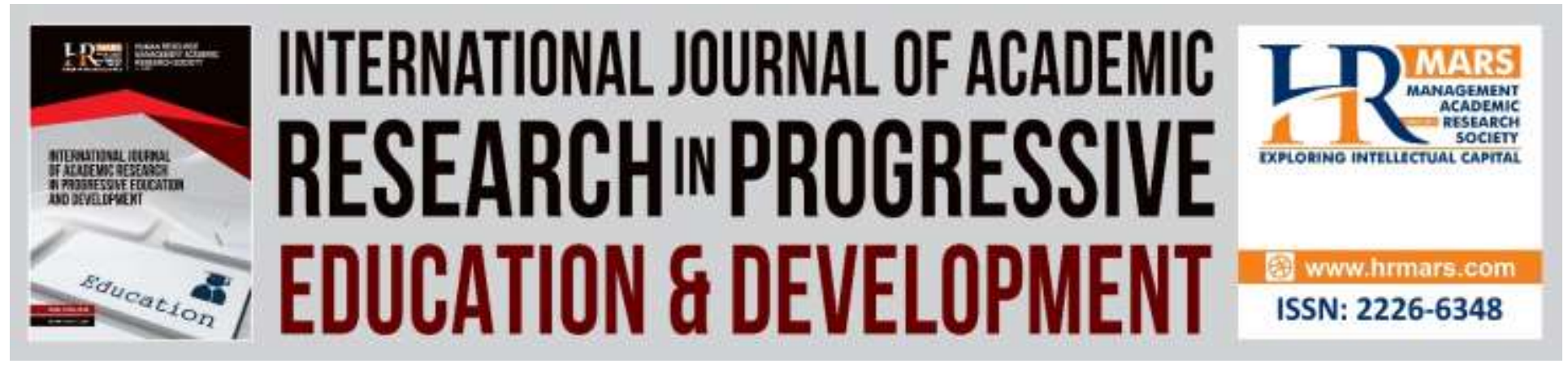

\title{
Issues and Challenges in the Design of Sustainability for Curriculum using WUSA (World Universities Sustainability Assessment)
}

Mohd Sayuti Hassan, Siti Fairuz Mohd Radzi, Vishanthini A/P Kanasan

To Link this Article: http://dx.doi.org/10.6007/IJARPED/v9-i2/7348 DOI:10.6007/IJARPED/v9-i2/7348

Received: 03 April 2020, Revised: 01 May 2020, Accepted: 26 May 2020

Published Online: 29 June 2020

In-Text Citation: (Hassan et al., 2020)

To Cite this Article: Hassan, M. S., Radzi, S. F. M., \& Kanasan, V. A. (2020). Issues and Challenges in the Design of Sustainability for Curriculum using WUSA (World Universities Sustainability Assessment). International Journal of Academic Research in Progressive Education and Development, 9(2), 334-344.

Copyright: (C) 2020 The Author(s)

Published by Human Resource Management Academic Research Society (www.hrmars.com)

This article is published under the Creative Commons Attribution (CC BY 4.0) license. Anyone may reproduce, distribute, translate and create derivative works of this article (for both commercial and non-commercial purposes), subject to full attribution to the original publication and authors. The full terms of this license may be seen at: http://creativecommons.org/licences/by/4.0/legalcode

Vol. 9(2) 2020, Pg. 334 - 344

http://hrmars.com/index.php/pages/detail/IJARPED JOURNAL HOMEPAGE

Full Terms \& Conditions of access and use can be found at http://hrmars.com/index.php/pages/detail/publication-ethics 


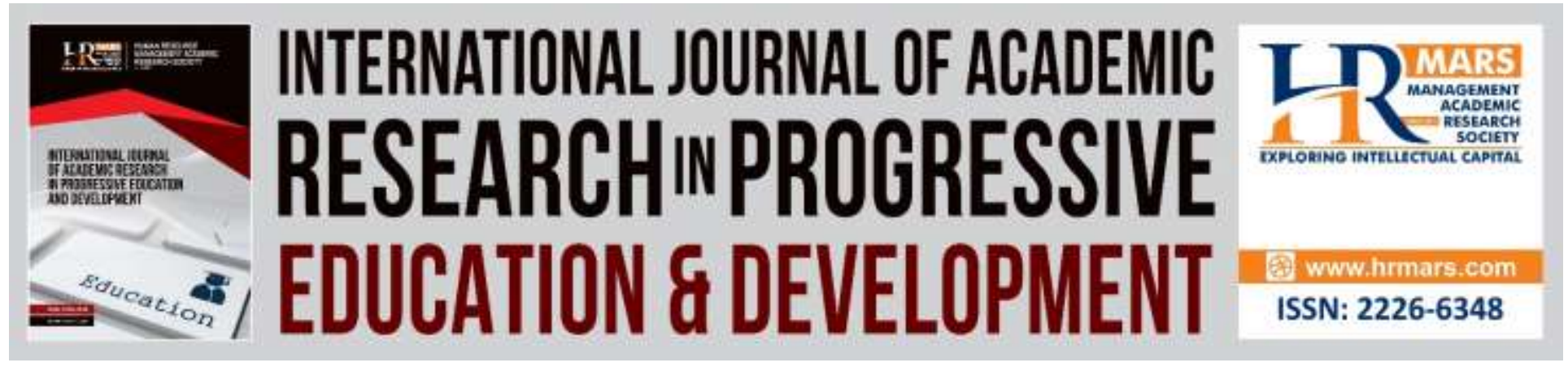

\title{
Issues and Challenges in the Design of Sustainability for Curriculum using WUSA (World Universities Sustainability Assessment)
}

\author{
Mohd Sayuti Hassan, Siti Fairuz Mohd Radzi, Vishanthini A/P \\ Kanasan \\ Center for Global Sustainability Studies (CGSS), Universiti Sains Malaysia, Main Campus \\ Email: sayuti@usm.my,fairuradzi@usm.my,vishanthini@student.usm.my
}

\begin{abstract}
Sustainability, which is influenced by the people's values and culture, is a development that meets the needs of the present without compromising the ability of future generations to meet their own needs; which is among all is education (UNESCO, 2009). A decade into the twenty-first century, the world faces substantial, complex and interlinked development and lifestyle challenges and problems. The challenges arise from values that have created unsustainable societies. We need a shared commitment to education that empowers people for change. Such education should be of a quality that provides values, knowledge, skills and competencies for sustainable living and participation in society, (Bonn Declaration, 2009). Education is unsustainable as the curriculum has no element of sustainability. Sustainability is not an easy topic to understand and assess. Frequently asked questions on sustainability are as such, "What determines sustainability?", "How to assess sustainability?", "Is it possible to rate sustainability?", "How to improve on sustainability?". WUSA is an innovative approach to gauge sustainability throughout university within its SD-ESD model, which combines the 'triple bottom line' of sustainability, environment economy and society with the triple bottom line mission areas of universities such as teaching, research and community engagement.
\end{abstract}

Keywords: Sustainability, Curriculum, Education, WUSA.

\section{Introduction}

The idea of sustainable development is created based on the concept and principle of continuous development with an objective to attend to the needs of the present without compromising the ability of future generations. Sustainable development concept comes to exist following the awareness on the importance of conservation and preservation of natural environment. Since that, elements related to geology and natural environment have received widespread attention in most countries across the globe that it becomes an eye opener and reminder to United Nations during its conference in 1972; "The 1972 United Nations Conference on Human Environment" 
(Mustafa and Jani, 1995). On the other hand, Pavlove (2004) stresses that sustainability concept has been a part of international discussion since the early 1980s. All organisations whether it is the government, private sector and non-government organisation bodies (NGOs) around the world have started taking a few initiatives towards the betterment of the life quality of future generation. It is clear that questions about the quality of life have been given serious attention at that time in order to ensure the well-being of the future generation so that sustainable lifestyle is able to be practised.

Issues related to development have been discussed seriously in the Earth Summit held in Rio De Janerio in 1992 and in Johannesburg in 26 August until 4 September 2002. The summit participants have discussed about the present development that does not fulfil the needs of future generation and results in a lot of bad implications. Malaysia as a proponent country that gives a full support towards Sustainable Development has included environmental sustainability issues parallel to economic development in Malaysia Long-Term plan through "Third Outline Perspective Plan 2001-2010".

One of the suggestions for Sustainable Development from Malaysia is Education for Sustainable Development (ESD). Education for Sustainable Development is also referring to learning that is needed to sustain and improve the life quality of future generation. In Malaysia, Sustainable Development concept has been introduced in the Seventh Malaysia Plan (RMK-7) in 1996. The importance of ESD has been identified as a global priority. Sterling (2001) states that the educational achievement will affect the economic prosperity of a country. While Coll, Taylor and Nathan (2003) suggest three ESD ways in which it can be developed in educational implementation within schools through learning experience, transferring of ESD knowledge from classroom to workplace and integrating ESD knowledge based on work.

\section{Curriculum - Educational Issues}

Transformation does not only take place in an educational organisation, but it involves transformation in curriculum as well. This is parallel to the aim that school is not only a place to prepare students that can fill specific job vacancies in the future but it is also a place that functions to provide a perfect and complete education that can guarantee and enable them to contribute towards self-development as well as for the people. It means that educational curriculum must possess a way or mechanism that can focus on the process to develop individual potential from every angle. Since the early existence of national education system, educational curriculum has also gone through various transformations or changes.

Now, after entering the new millennium of the $21^{\text {st }}$ century, the world's community has passed through yet another phase of paradigm shift of life. It covers the shifting from industrial community into informative community; from using human technology into the innovation of high technology device; from power centralisation into power distribution; from hierarchical concept into networking concept; from local economy into international economy; and from short-term plan into long-term plan. 
In the book of Education Development 2001-2010 (KPM, 2001), Ministry of Education Malaysia states that education development from the Era of Policy Development to the Era of National Vision Policy has succeeded to achieve numerous improvement, specifically in providing infrastructure, education facilities and teaching training. The strategy to enhance education opportunity succeeded to reach its goal. However, there are various issues that are presently being raised regarding the achievement of National Education Policy, such as ones related to education structure; access to education; equity; teachers' quality; imbalance of infrastructure preparation; implementation of PPSMI Program; and curriculum relevance. This is in line with the opinion by Hussin (2004) that states there are a lot of education issues that can be categorised into administration, educational level, education technology, school organisation and teacher training.

Several issues relate to education structure including secondary education structure that is not standardised, in which it does not really fulfil the requirement, for example: The schooling years in Malaysia education structure is different with most of other countries in the world. There is no standardisation in the entries to Higher Education (IPT) because of the existence of various channels; most students choose to finish their schooling after Sijil Pelajaran Malaysia (SPM); and that the curriculum scope for Form 1 until Form 6 is very broad.

There are recent issues that require attention. These issues are the main present challenges in the country's education system as well as the outside world. A few issues that are needed for the sustainability of education system have been analysed, such as:

\section{a) Curriculum Development Cycle Model}

Research in a few countries has found that the cycle period of a particular curriculum takes about 5 to 10 years. In Japan, for example, the period of one curriculum cycle was 5 years before it is revised. In Malaysia, there is no clear period for development and implementation cycle of any education schooling programme until higher education studies such as at the local universities.

\section{b) Curriculum Development and Appropriation}

Development process and appropriation of a curriculum faces a lot of problems and challenges. All levels of development are in fact facing a few problems and issues that need to be taken care of. There are also many other parties that do not really agree with suggestions related to the curriculum that has been identified. It is the same for developing a particular curriculum that is more sustainable than the past; it is a challenge that seeks for attention.

\section{c) Implementation Level}

Any particular curriculum that is being appropriated in a centralized manner has the strength, policy and priority but in real situation, it is very different even at the most basic level in terms of facilities and communication. Serious problem is possible to occur at the implementation level if there is a huge gap and weakness between the planning and the executor. This is also a challenge that is hard to deal especially by future generation in order to make sure their life in the future to be more sustainable. 
Vol. 9, No. 2, 2020, E-ISSN: 2226-6348@ 2020 HRMARS

d) Further Actions After Implementation

Post-implementation activities are very important to ensure the effectiveness and improvement towards any changes. Monitoring and supervision, counselling service and frequent guidance can improve teachers' motivation and morale. It can be a burden in a way because it requires involvement of the teachers or educators who possess high level skills to ensure every implementation to be on the right track.

e) Decision Is Made Collectively

One of the strengths from centralised education system is that every decision is made collectively, involving all levels of administration. Although there is agency responsible to plan and appropriate the curriculum, in reality, the planning process is shared together with various parties and all decisions are collectively made. When decision is made collectively, it is almost certain that there will be educators who do not agree to certain elements in it for particular reasons. This will make it hard for other parties to ensure the decision made is more sustainable and it gives benefits to all parties.

\section{f) Problem from Standardised Curriculum For All}

The same curriculum prepared for all is unable to attend to all the demand and background of all different students. School children from the rural area possess different experience from city children. Assumptions towards the curriculum content are that they do not consider what is brought by the students to the classroom in terms of their early knowledge and culture. There are people with the opinion that the curriculum is bias towards experience in the City or urban environment. This can raise inconvenience among the students during learning to the point that causes them to lose interest and decide to end their schooling years early.

Problems as well as issues that arise require patience in terms of appropriation and implementation. Hence, it is indeed needs to be taken care more thoroughly so that it can fulfil the needs of all parties. Oliva (2005) mentions about ten axioms related to curriculum development principles. One of the axioms is "curriculum development is a never-ending process".

\section{Sustainability in Education}

Educational sustainability refers to learning needed to conserve and improve life quality for future generation (Majzub, 2005). In December 2002, UNESCO has also announced that the year 2005 until 2014 as the education decade for Sustainable Development.

Each country will ensure that improvement to the system is a continuous effort to expand individual potential completely and in an integrated manner in order to develop an individual who is balanced, harmonic and with high morale. It clearly shows the effort to give birth to a progressive community that can contribute to the development of the country. Continuous effort to further enhance individual potential in order to develop individual who is balanced, harmonic and with high level of morale is with the aim to conserve and ensure a better life quality of future generation. Hence, Education for Sustainable Development at school or faculty is with 
a hope to achieve the objective and fulfil educational sustainability concept. Based on Mohamad (2001), Sustainable Development through education is a latest innovation in education reformation that starts from natural environment education. Education for Sustainable Development enables human being to build knowledge, values and skills to take part in decisions making on the ways we do something, be it individually or collectively, locally or globally that will enhance present life quality without damaging the planet in the future.

Besides that, Hopkins (2005) states that even though the entire world acknowledges the importance of education to achieve sustainable development, it is unfortunate that up until now the achievement is still quite limited. Nations University (UNU) and Institute of Advanced Studies (IAS), European Network of the UNESCO, International Forum on Education for Sustainable Development, Beijing have conducted discussion and forum but the education implementation for Sustainable Development is quite slow. Education systems in most countries do not carry out learning activity that focuses the attention to the main issues in sustainable development. Research by UN Economic Commission for Europe (UNECE) in 2006 has identified several issues and constraints in education implementation for sustainable development. Some of them are the lack of understanding on the concept of sustainable development, to not understand the meaning of education for sustainable development, lack of allocation to carry out projects related to education for sustainable development. Apart from that, the lack of support and role played by other bodies whether it is the government or non-government as well as media towards education for Sustainable Development affect the understanding of teachers and administrators to understand the meaning of ESD itself. In vocational education, on the other hand, ESD is not understood broadly.

Another research conducted by Pavlova (2004; 2006) and Pavlova \& Lebeame (2004) in France, Australia and Russia to obtain perceptions from technology teachers towards sustainability including sustainability issues in the syllabus in technology subject. Result from the research found that the technology teachers do not participate in education for sustainable development. Most pre-service teachers and teachers who are teaching in the three countries do not possess fair knowledge on the meaning of Sustainable Development or education for Sustainable Development. In relation to that, Pavlova (2008) suggests for a guideline to implement educational concept for Sustainable Development through teaching and learning by the teachers to exist.

\section{Sustainable Development Strategy for Education}

The Bonn Declaration (2004) states that Sustainable Development for Education should be able to make sure a worker to have the knowledge, competency, skills, values and attitude to develop a citizen who is responsible and productive, that always appreciate the execution of good work and further to produce sustainable community. Besides that, Sustainable Development should renew the skills of an individual. Research has been carried out on labour marketing that is aware of rules and conditions of certain skills and transformation towards the working world. Among the requirements that every worker must possess are k-worker, generic or soft skills, re-training, continuous learning, workers' role in community, skills development, committed and 
motivational, k-economy and to always think critically as well as able to solve problems. In Malaysia context, in order to achieve the vision of 2020, it needs more knowledgeable workers (Yunos, 2004). In addition to that, teachers should also possess high knowledge and skills in the field that they teach. It is necessary so that a teacher will be more confident in teaching and it will affect the students that they teach (Ishak, 2002). Hence, re-orientation for Sustainable Development should be made. It is not only limited to the content of the courses and curriculum development but also covers the whole teaching system. It includes a few aspects such as implementation, policy development, administration, teacher training and allocation (UNESCOUNEVOC 2004b). Apart from that, there are also a few sustainability strategies highlighted by UNEVOC that need to be studied to ensure sustainable development in teaching can be well implemented. Seven strategies being highlighted by UNEVOC are; (i) Support and country's vision, (ii) Support to study the country's policy, (iii) Guidelines for planning and implementation, (iv) Capability building and training program, (v) Support the development of material resource and learning equipment, (vi) Establish relationship and partnership and (vii) Continuous monitor, evaluation and research.

\section{Wusa (World University Sustainability Assessment)}

We have developed a new tool WUSA to monitor and mainstream sustainability throughout Universiti Sains Malaysia, in keeping with our new vision of "Transforming Higher Education for a Sustainable Tomorrow." The outcomes by using WUSA are to provide feedback and guidance to all practitioners to build sustainability content in their mission activities. This may include reorienting the existing courses or designing and managing new research and communityoriented projects. Together, the results may be used either for rating or ranking sustainability performance.

WUSA using a set of Sustainability Indicators (SI) that we had identified and is used to assess the sustainability content of existing courses and subjects, research projects and community initiatives. An Indicator Framework and a set of four Indicator Worksheets, both aligned to the USM-APEX sustainability roadmap, were developed to assist in the successful evaluation, design, and implementation of sustainability mainstreaming throughout the university in teaching, research, community engagement and institutional arrangement.

WUSA such as a holistic set of sustainability indicators is of crucial importance as USM adopts the standpoint that sustainability integration is a process which has to occur within all levels of an organization's activities and is in synchronize with its own objectives, targets and processes.

Figure 1.1 below shows how WUSA operates starting with input files (in WORD or PDF form) in which every file will be read word by word until the content of the text is finished. The words will be compared with all the indicators in the Database. The output produced is in percentage form and it can also be produced in Pie Chart, Table and other versions. From the result gained, it will ease us to make improvement in the syllabus of the courses being taught in universities to ensure sustainability elements to exist with a high percentage. Compared to other methods, WUSA only needs five seconds to produce output in every processing. 


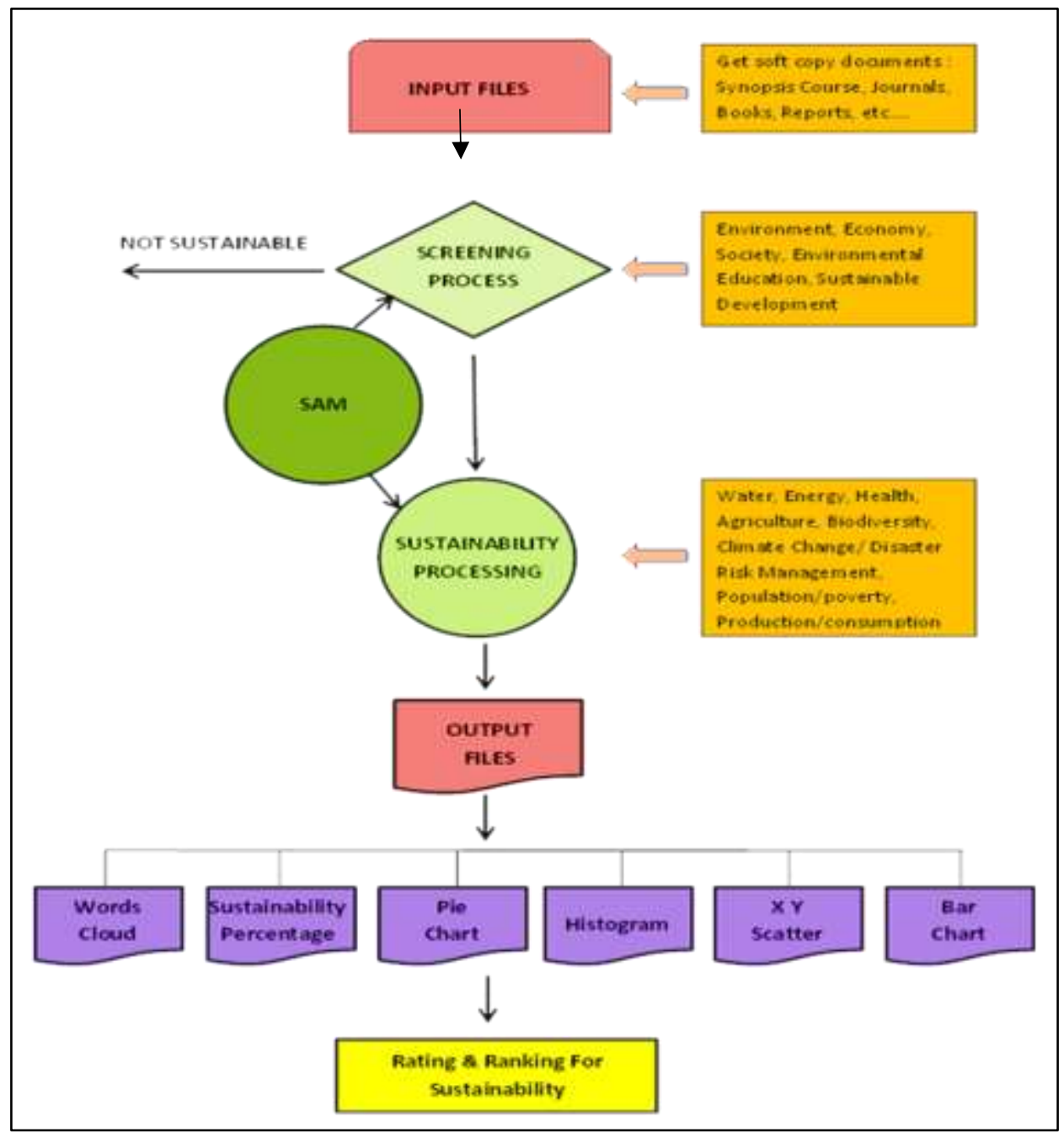

Figure 1.1: WUSA Flowchart

Source: Center for Global Sustainability Studies, Universiti Sains Malaysia

\section{Course Assessment in Universiti Sains Malaysia}

A research has been conducted by using WUSA to determine the level of sustainability for three schools which are School of Computer Science, School of Pharmaceutical Science and School of Biological Science for all courses handled. From Table 1.1, it shows that the total percentage is quite small overall in which School of Computer Science obtains $9.68 \%$ of sustainability, School of Pharmaceutical Science with 10.89\% and School of Biological Science with $17.36 \%$.

While for SD-ESD (Sustainable Development - Education for Sustainable Development) element, the total percentage for School of Computer Science is $18.10 \%$ of sustainability, School of Pharmaceutical Science with $15.32 \%$ and School of Biological Science scores $22.91 \%$ of sustainability.

With the result shown thus the schools need to take initiative to revise it in detail to find the cause for such result. All the criteria need to be re-checked such as Environment, Economy, 
Society, Environmental education / sustainability development, Water Energy, Health, Agriculture, Biodiversity, Climate change /disaster risk management, Population / poverty, Production / consumption.

Table 1.1 : Schools' Sustainability Percentage

\begin{tabular}{|l|c|c|c|}
\hline CRITERIA TYPE & $\begin{array}{c}\text { B.Sc (Science) Comp } \\
\text { Sc : School OF } \\
\text { Computer Science }\end{array}$ & $\begin{array}{c}\text { B.Sc (Science) } \\
\text { Farmasi : School of } \\
\text { Pharmaceutical } \\
\text { Sciences }\end{array}$ & $\begin{array}{c}\text { B.Sc (Science) } \\
\text { Biology : School of } \\
\text { Biological Sciences }\end{array}$ \\
\hline ENVIRONMENT & 16.67 & 8.34 & 49.31 \\
\hline ECONOMY & 22.65 & 18.04 & 16.37 \\
\hline SOCIETY & 12.97 & 14.82 & 12.97 \\
\hline $\begin{array}{l}\text { ENVIRONMENTAL EDUCATION / } \\
\text { SUSTAINABILITY DEVELOPMENT }\end{array}$ & 20.1 & 20.1 & 12.99 \\
\hline WATER & 6.67 & 7.5 & 14.17 \\
\hline ENERGY & 6.2 & 2.63 & 14.1 \\
\hline HEALTH & 2.63 & 10.4 & 2.63 \\
\hline AGRICULTURE & 0 & 7.5 & 25.63 \\
\hline BIODIVERSITY & 3.57 & 17.86 & 28.57 \\
\hline CLIMATE CHANGE /DISASTER RISK & 2.18 & 4.35 & 10.69 \\
\hline MANAGEMENT & 10.12 & 11.84 & 13.56 \\
\hline POPULATION / POVERTY & 12.38 & 7.26 & 7.38 \\
\hline PRODUCTION / CONSUMPTION & 18.1 & 15.32 & 22.91 \\
\hline RESULT BY CATEGORY & $\mathbf{3 . 8 1}$ & 9.18 & 17.02 \\
\hline SD - ESD & $\mathbf{8 . 2 2}$ & 7.82 & 10.54 \\
\hline WEHAB & 9.68 & 10.89 & 17.36 \\
\hline CROSS SECTORIAL (+3) & & & \\
\hline TOTAL AVERAGE OF SUSTAINABILITY & & & \\
\hline Total Average & & & \\
\hline
\end{tabular}

Source : Center for Global Sustainability Studies, Universiti Sains Malaysia

\section{Conclusion}

Education for Sustainable Development in curriculum is a crucial step and supposedly to gain appropriate attention to ensure the education system is able to be mainstreamed in this country. It can also be developed parallel to current demand that stresses on Sustainable Development in education at the same time. ESD also takes part in the effort towards sustainable education to ensure it is not left behind in the fast pace of the modern time across the world. Through ESD presented in this paper work, responsible parties should play their roles in order for it to be realised and implemented. ESD can at least help responsible parties to obtain guidelines to shape and further make a transformation in education across the country or globally.

Education for sustainability is both present and future-oriented. It is about learning to design and implement actions for the present, within the knowledge that the impact of these actions will be experienced in the future. Through education, it leads students to develop an overall capacity to contribute to "a more sustainable future in terms of environmental integrity, economic viability, and a just society for present and future generations", (UNESCO, 2009). 
The unsustainable practices in the current curriculum have minimally achieved a sense of sustainable lifestyle and practice among the current generation. As the result, promoting the capacity-building opportunities that harness the ability of individuals to act as agents of change is far from success as the curriculum has only minimally able to assist students to develop skills that will influence a change within a system, organisation or wider society. Further, the integration, transformation and innovation are less likely to succeed within an organisation as the individual is unable to practise the future thinking that leads to a better lifestyle.

\section{Acknowledgment}

The authors would like to thank BRIDGING Grant, Universiti Sains Malaysia (Research Title: How Local Governments Can Steer Cities towards Sustainability and Resilience - Project Code: 6316190) for financial support. Authors are also grateful to the anonymous reviewers for their insightful suggestions and careful reading of the manuscript.

\section{References}

Coll, R.K., Taylor, N. \& Nathan, S. (2003). Using Work-based Learning to Develop Education for Sustainability: A proposal. Journal of Vocational Education and Training 55(2): 120-131.

Hopkins, C. (2005). Role of higher education in the pursuit of a sustainable future, paper Presentation in Regional Workshop on Education for Sustainable Development, USM, Penang.

Ishak, I. Z. (2002). Kualiti pensyarah politeknik lepasan sarjana pendidikan Kolej Universiti Teknologi Tun Hussein Onn (KUiTTHO): Projek Sarjana Teknik dan Vokasional. KUITTHO.

Yunos, J. M. (2004). View from the field. UNESCO International Meeting on Innovation and Excellence in TVET Teacher/Trainer Education. 8-10 November 2004, Hangzhou, China.

Ministry of Education, Malaysia (KPM). (2001). Pembangunan Pendidikan.

Mustapha, N. H., Jani, M. F. M. (1995). Pembangunan Pertanian Lestari. Bangi:

Penerbit Universiti Kebangsaan Malaysia.

Pavlova, M. (2004). Sustainable development: Is it an educational priority for French Students?.DIm Middleton, H., Pavlova, M. \& Roebuck, D. (pnyt.).Learning for Innovation in technology education (3): 36-45. Proceeding of the 3rd International Conference on Technology Education Research: Centre for Learning Research, Griffith University.

Pavlova, M. (2006). Technology education for sustainable futures. Design and Technology Education: An International Journal 11(2): 41-53.

Pavlova, M. (2008). Technology and Vocational Education: A framework for the Development of teaching approaches and resources for Education for Sustainable Development. DIm j.Fien, Maclean, R. \& Park, M.G. (pnty.).Work, learning and Sustainable development: Opportunities and Challenges: 455-464. Dordrecht: Springer.

Oliva, P. F. (2005), Developing the curriculum (6 $6^{\text {th }}$ ed). Boston: Pearson Education, Inc. 
INTERNATIONAL JOURNAL OF ACADEMIC RESEARCH IN PROGRESSIVE EDUCATION AND

DEVELOPMENT

Vol. 9, No. 2, 2020, E-ISSN: 2226-6348 @ 2020 HRMARS

Majzub, R. (2005). Model Latihan Perguruan Glokal untuk Pembangunan Lestari. Prosiding. Sterling, S. (2001). Sustainable Education: Revisioning Learning and Change. UK: Greenbook.

Hussin, S. (2004). Pendidikan di Malaysia : sejarah, sistem dan falsafah.

The Bonn Declaration. (2004). Learning for Work, Citizenships and Sustainability: a UNESCO meeting of International Experts on Technical and Vocational Education And Training. Bonn, Germany, 25-28 October 2004.

UNESCO. (2004). Suggestions to UNESCO for Action Planning in TVET for Sustainable Development. Expert Meeting on Learning for Work, Citizenship and Sustainability, Bonn, October 2004. UNESCO, Paris

http://www.unevoc.unesco.org/publications/pdf/SD_ActionPlan_e.pdf [6 Ogos 2008].

Mohamad, Z. F. (2001). Curriculum: Implementing Education for Sustainable Development at the University Malaya. University Leaders for a Sustainable Development Future 5(1) 504 